Review

\title{
A new dawn for the use of traditional Chinese medicine in cancer therapy Harendra S Parekh*1, Gang Liu ${ }^{2}$ and Ming Q Wei ${ }^{2}$
}

\begin{abstract}
Address: ${ }^{1}$ The University of Queensland, School of Pharmacy, St Lucia QLD 4072, Brisbane, Australia and ${ }^{2}$ Division of Molecular and Gene Therapies, School of Medical Science - Griffith Health, Gold Coast Campus, Griffith University, Brisbane, QLD 4222, Australia

Email: Harendra S Parekh* - h.parekh@pharmacy.uq.edu.au; Gang Liu - heroliugang@hotmail.com; Ming Q Wei - m.wei@griffith.edu.au

* Corresponding author
\end{abstract}

Published: 20 March 2009

Molecular Cancer 2009, 8:21 doi:10.1 |86/|476-4598-8-2I

This article is available from: http://www.molecular-cancer.com/content/8/I/2I

(C) 2009 Parekh et al; licensee BioMed Central Ltd.

This is an Open Access article distributed under the terms of the Creative Commons Attribution License (http://creativecommons.org/licenses/by/2.0), which permits unrestricted use, distribution, and reproduction in any medium, provided the original work is properly cited.
Received: 10 November 2008

Accepted: 20 March 2009

\begin{abstract}
Although traditional Chinese medicine has benefitted one fifth of the world's population in treating a plethora of diseases, its acceptance as a real therapeutic option by the West is only now emerging. In light of a new wave of recognition being given to traditional Chinese medicine by health professionals and regulatory bodies in the West, an understanding of their molecular basis and highlighting potential future applications of a proven group of traditional Chinese medicine in the treatment of a variety of cancers is crucial - this is where their calling holds much hope and promise in both animal and human trials. Furthermore, the rationale for combining conventional agents and modern biotechnological approaches to the delivery of traditional Chinese medicine is an avenue set to revolutionize the future practice of cancer medicine - and this may well bring on a new dawn of therapeutic strategies where East truly meets West.
\end{abstract}

\section{Introduction}

Reports of therapeutic success with traditional Chinese medicine (TCM) have until very recently been met with much scepticism and pessimism by the West, due in-part to the sheer lack of available credible and rigorous clinical data and at claims that a given TCM can remedy common ailments and be just as efficacious in eliminating life threatening diseases, such as cancer. The tide is now beginning to turn on this negative outlook, aided by the ever-increasing migration of people and along with them knowledge (based upon ancestral cultural influences) from two of the world's fasting growing populations, China and India, to the West [1]. This translation to the West of ancient complementary and alternative medicine formularies and their ever-increasing integrative role in the armoury against cancer means that their presence and place in modern medicine can no longer be overlooked, by regulatory authorities and clinicians alike, as being merely anecdotal.

The age-old holistic approach employed by Chinese practitioners proposes that a multitude of events are key to returning a patient to a healthy state; where cancer therapy is concerned these primarily include an interplay between the induction of apoptosis/cell-cycle arrest, inhibition of angiogenesis, overcoming multidrug resistance (MDR), and boosting the immune system (Figure 1). Following an extensive review of the literature we describe the detailed molecular basis of a proven group of TCM, and highlight reported synergies when administered alongside so-called 'conventional therapies' in tumour cell regulation and in bringing about homeostasis. 


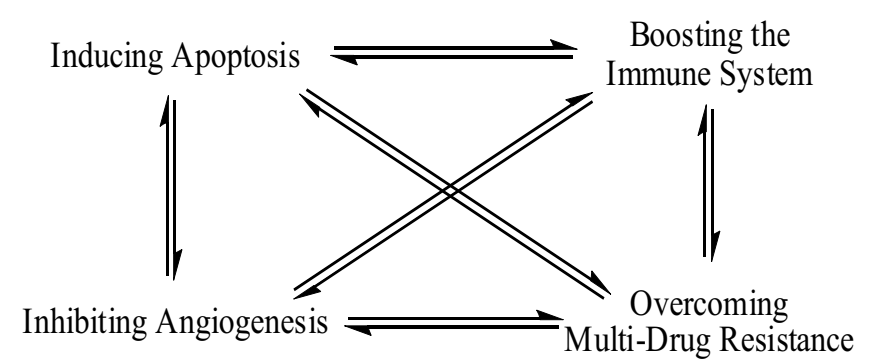

Figure I

The complex interplay between the primary mechanisms of TCM.

The many physiological growth control mechanisms that regulate cell proliferation and tissue homeostasis are linked to apoptosis and it follows that resistance developed to this 'programmed cell death' can be directly linked to prolonged tumour cell survival and resistance to therapy $[2,3]$. The processes resulting in apoptosis are mediated by extrinsic (via death receptors) or intrinsic (via mitochondrial) pathways and although their paths are not mutually exclusive, evidence suggests the latter certainly predominates where TCM is concerned [4]. Here we look in some detail at two of the primary mechanisms 'apoptosis' and 'angiogenesis' in the context of TCM, proposed to be key avenues responsible for imparting therapeutic efficacy against a wide range of cancers.

\section{Molecular basis of TCM - Apoptosis}

Apoptosis is guided by a range of complex multi-step, multi-pathway programs that eventuate in the breakdown of cellular DNA leading to cell death [5]. And by far the most emphasized and reported endpoint in TCM trials todate have been those of cell cycle arrest and apoptosis $[6,7]$. The cascade of intracellular events triggering cell death have been identified to involve activation or suppression of a number of key receptors, genes and enzymes [8]. The mitochondria, a cell's energy source, is recognized as playing a central role in the sustained survival of cells and many of the triggers to apoptosis are known to act here, either directly or indirectly $[9,10]$.

\section{Apoptosis by the 'Caspase' effect}

Of the pro-apoptotic enzymes implicated in TCM activity the family of cysteine proteases, commonly termed 'caspases' are key players with their role and function extensively reviewed elsewhere $[2,3,10]$. Briefly, caspases are divided into two broad groups, the 'initiators' and the 'executioners' and once activated they go on to activate other pro-caspases that trigger apoptosis. The primary role of 'initiator' caspases (caspase-8, $-9 \&-10$ ) is the processing and activation of both pro-enzymes (procaspase-8, -9 \& -10) and 'executioner' caspases (mainly caspase-3, -6, \& -7) [2]. Pro-caspases are inactive forms of their cousins, the caspases, and any processing of these pro-enzymes is regarded as a reliable marker for caspase activation, and so apoptosis. It is the result of 'executioner' caspases cleaving each other that triggers an amplifying proteolytic cascade, effecting cleavage/degradation of cellular substrates these aptly named 'death' substrates are responsible for signalling biochemical and morphological changes that eventuate in cell death [11].

\section{Apoptosis by NF-Kb}

Cellular stress is invoked by an imbalance in a cell's redox state. Nuclear factor- $\kappa \mathrm{B}(\mathrm{NF}-\kappa \mathrm{B})$ is a key regulatory molecule, activated when a cell experiences oxidative stress [12]. It is well-documented that tumour necrosis factor- $\alpha$ (TNF- $\alpha$ ) and the closely related tumour necrosis factorrelated apoptosis ligand (TRAIL) along with lipopolysaccharides, interleukins (IL) and UV or IR radiation all impart cellular stress that triggers the NF- $\kappa \mathrm{B}$ cascade $[13,14]$. NF- $\mathrm{B}$ ordinarily resides in the cytosol of nonstressed cells, non-covalently bound to the family of inhibitory $-\kappa \mathrm{B}(\mathrm{I} \kappa \mathrm{B})$ proteins which function to mask the nuclear localization signal (NLS) present on NF- $\kappa$ B. When the redox balance of the cell is perturbed by extracellular stimuli, IкBs are rapidly degraded exposing the NLS. The consequence is transfer of NF- $\kappa \mathrm{B}$ to the nucleus where it regulates gene expression, the products of which are directly involved in tumorigenesis $[15,16]$.

\section{Apoptosis by TCM}

Numerous studies have been aimed at deciphering the precise molecular basis for a variety of TCM and those most noteworthy are discussed below.

The root of Scutellaria Baicalensis (Figure 2), commonly referred to as 'Baikal skullcap', 'Huang qin' or the 'Golden Root', is probably one of the most widely used herbs in TCM preparations with its flavonoid-rich elements considered to impart anti-inflammatory, anti-viral, anti-bacterial and anti-neoplastic activity [17-20].

It is also one of the most widely studied by researchers, being used either alone or more often in combination with other TCM for a range of cancers (in vitro and in vivo), namely of the prostate, breast, lung, liver and ovaries [6,21-23]. The roots chief therapeutic ingredient is baicalin, although it is converted to baicalein by intestinal gut flora with this latter bioactive firmly considered to be the primary active constituent responsible for its pro-apoptotic and anti-proliferative effects [21]. Extensive studies reveal that other flavonoids present within the herb e.g. neobaicalein, wogonin and wogonoside are also at work and that their co-synergies most likely contribute to the observed efficacy [24]. The principle mechanism of action of Scutellaria Baicalensi is via the inhibition of eicosanoid synthesis - being important mediators of pro-inflamma- 


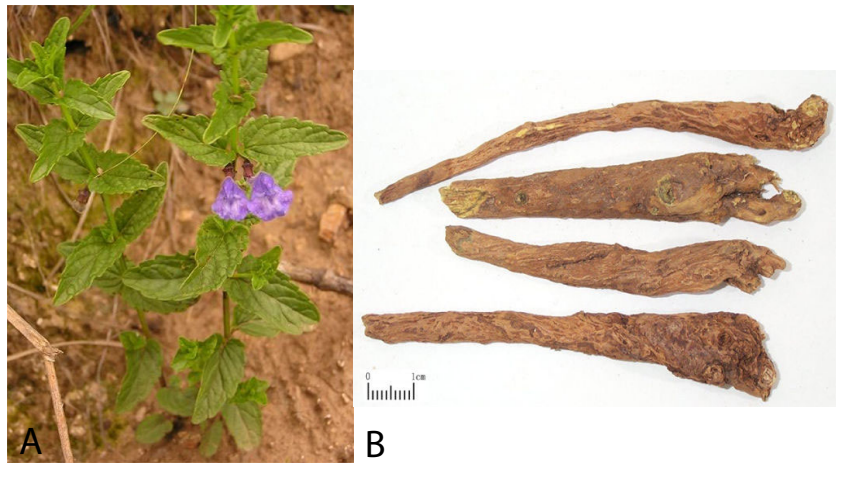

Figure 2

Plant (A) and root (B) of Scutellaria Baicalensis ('golden root') where root scale is shown as $\mathbf{I ~ c m}$.

tory (cyclooxygenase-2 (Cox-2)) and tumour cell proliferatory (lipoxygenase) markers [25]. Simultaneous inhibition of Cox-2 and 12-lipooxygenase has been shown to result in both reduced inflammation and tumorigenesis $[25,26]$. The role of baicalein against cell proliferation in PC-3 and DU145 prostate cancer cell lines is that of cell cycle arrest (at $\left.\mathrm{G}_{0}-\mathrm{G}_{1}\right)$ while also inducing apoptosis - confirmed via detection of caspase-3, at concentrations typical for administration to humans [27].

Further evidence of TCM acting via caspase activation and NF-кB also exists with Takrisodokyeum (TRSDY) - comprising 12 herbs in various proportions [28]. Caspase-3 activity assays conducted by Kwon et al on promyelocytic leukeamic cells (HL-60) cells pre-treated with TRSDY revealed that apoptotic cell death was indeed caspase-3 induced [27]. Its activation resulting in classical apoptotic signs including DNA fragmentation, chromatin condensation and plasma membrane blebbing $[29,30]$. Introduction of a caspase- 3 inhibitor resulted in no detectable caspase- 3 production and the downfield cleavage of cellular death substrates was also absent. It was further identified that oxidative stress by way of hydrogen peroxide generation was a co-contributor to apoptosis in the same population of cells. In an attempt to elucidate which of caspase-3 or hydrogen peroxide was generated first, cells were pre-treated with an antioxidant and scavenger, quenching any oxidative agent. Levels of caspase-3 were found to be negligible in this case, strengthening the hypothesis that caspase- 3 activation does not take place in these cells without prior oxidative stress $[31,32]$. Whether intracellular events leading to apoptosis follow this sequence of events in other cancer cell lines using this or other TCM is yet to be determined although parallel studies using other TCM do concur that activity is via selective members of the caspase family, namely caspase-3 [33-36].

TRAIL has received considerable attention by researchers since the discovery that most cancer cells are sensitive to its apoptotic effect but that normal cells confer resistance to it [37]. The potential of TRAIL as a realistic future therapy against cancer was further encouraged by the discovery that conventional therapy, namely chemotherapy or $\gamma$ irradiation can sensitize cells previously resistant to TRAIL [38-40]. The bioactive Triptolide (PG490) - extracted from the TCM Tripterygium wilfordii has been studied extensively for anti-inflammatory and immunosuppressive activity, being shown to sensitize various types of tumour cells to apoptosis induced by TRAIL, TNF- $\alpha$ and chemotherapy [41-44]. A study conducted by Frese et al evaluating PG490 suggests that it sensitizes previously resistant Calu-1 lung cancer cell lines to TRAIL-induced apoptosis while sparing normal human bronchial epithelial cells [42]. PG490-mediated sensitization of the cells to TRAIL requires activation of a family of extracellular-regulated protein kinases (ERK's), namely ERK-1. Located in the intracellular environment ERK-1 is thought to be the crucial link bridging the process that follows death receptor activation and precedes caspase activation. TRAIL, acting via death receptors (TRAIL-R1 \& R2) forms a deathinducing signalling complex (DISC); this then recruits an 'initiator', caspase-8, which begins a cascade of protease activation enlisting the 'executioner' - caspase-3, promoting cleavage of death substrates with the end-point being cell death. [45-47]. Carter et al confirmed the role of PG490 in apoptosis and went further to highlight that mitochondria, and not the death receptor, predominate in PG490 activity in mouse embryonic fibroblasts, due to caspase-9 activation [48]. This contradicted the findings of Frese et al where caspase- 8 was found to be the key proenzyme in triggering apoptosis highlighting that mechanistic variability indeed exists with TCM as would be expected, thus caution must be taken when making any broad claims relating to their precise mechanism of action [42]. Synergistic induction of apoptosis has also been observed when chemotherapeutic agents are employed together with PG490, further corroborating the case for TCM use with conventional anticancer agents [48].

All cancer cells possess an elevated apoptotic threshold and although the therapeutic interventions of chemotherapy and $\gamma$-irradiation are crucial they are commonly plagued with resistance, resulting in a cycle of remission and relapse. The ever-rising incidence of resistance to chemotherapy suggests an increase in this apoptotic threshold and so the challenge is whether it can be reduced sufficiently to break the cycle at the point of remission. Advances made in recognizing and activating the key molecules involved in apoptotic pathways are certainly very encouraging from the perspective of eradicating a tumour although resistance to these interventions are also emerging [49]. The growing acceptance of TCM as a real adjunct therapy makes it an invaluable tool in the fight against many cancers and it holds much promise especially in cases where resistance to therapy is prevalent. 


\section{Molecular basis of TCM - Angiogenesis}

Angiogenesis - the creation of a healthy vascularised network by a tumour is a key underlying process in the induction and establishment of cancer [50]. It, like apoptosis, involves multi-step biochemical interactions that require activation of cell-signalling pathways, supply of nutrients and a host immune response. A range of TCM such as the Chinese wormwood (Artemisia absinthium - Figure 3), turmeric (Curcuma longa - Figure 4) and Scutellaria Baicalensis are commonly employed by traditional practitioners and studies demonstrate that their actions are at least in-part achieved by blocking the critical process of tumour vascularisation [51]. In order for cancer cells to grow and develop a healthy network of blood vessels high sources of nutrients and oxygen are vital. The rapidly dividing cells are subject to a hypoxic environment, so failure to set-up this fundamental framework results in stunted growth of the tumour ( $\leq 1-2 \mathrm{~mm})$ and development of necrosis at its core $[52,53]$. Starving an established tumour of its blood supply involves an intervention in the complex angiogenic cascade, of which vascular endothelial growth factor (VEGF) is the most reported biomarker [54]. VEGF production is considered essential for angiogenesis and cancer metastasis, with high titres being indicative of a poor prognosis [55]. A wide array of oncogenes (e.g. ras, HER-2, p53 and C-jun) and growth factors (EGF, TGF, IGF and PDGF) have been identified as up-regulating VEGF-mRNA and so TCM that inhibits their expression and production, respectively, are also considered invaluable tools in cancer therapy.

Artemisinin, an active constituent of Chinese wormwood (Artemisia absinthium - Figure 3) is a potent antimalarial, however more recently it has been shown to possess antiangiogenic properties, acting by lowering both VEGF and its receptor (VEGF-R2(in embryo), KDR(in humans) and flk-1(in mice)) in tumour and endothelial cells in a dosedependent manner [56-59].

Phytochemicals have long been used as 'lead compounds' to generate drugs with better pharmacokinetic profiles and reduced toxicity in vivo. Artesunate (ART) and dihydro-ART are semi-synthetic derivatives of artemisinin with demonstrable activity against a wide range of cancer cell lines including KML-562 (chronic myeloid leukaemia), HeLa (cervical cancer) and HO-8910 (ovarian cancer) [60-62]. Human umbilical vein endothelial cells (HUVECs) are commonly employed alongside cancer cell assays to assess the extent to which angiogenesis is induced by way of new micro-vessel tube formation. Studies using this model show that dihydro-ART has significant anti-angiogenic activity compared to ART and prevents new-microvessel formation by $70-90 \%$ in vitro [61]. Along with the low toxicity profile associated with

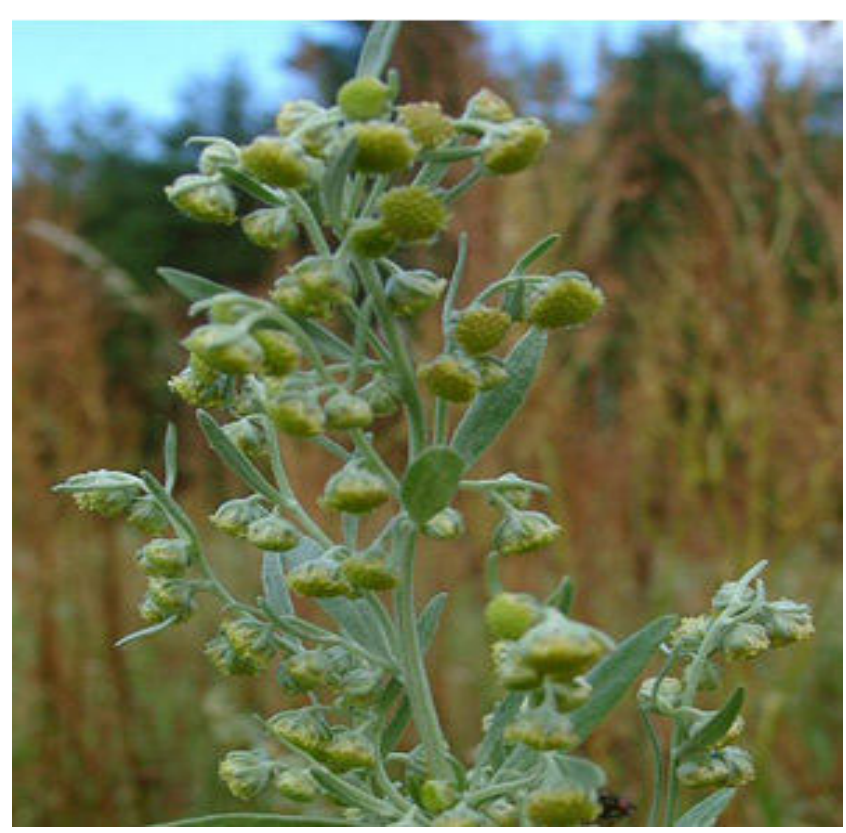

Figure 3

Plant of Artemisia absinthium ('Chinese wormwood').

these agents their future role to complement treatment regimes is encouraging and warrants further investigation.

Curcumin (Curcuma longa - Figure 4), the principle curcuminoid in turmeric and widely used culinary spice is cytotoxic to cancer cells on a number of levels with a proven synergy when used in combination with chemotherapy/ radiotherapy [63-65]. Its angioinhibitory action has been substantiated in a number of cancer cell lines including that of the breast where it was found to inhibit two major angiogenic factors, VEGF and b-FGF (basic-fibroblast growth factor) $[66,67]$. Besides this it also impedes tumour cell invasion, a property found to diminish circulating but not established metastases. It does this via downregulation of matrix metalloproteinases (MMP), most notably MMP-2 \& MMP-9 - responsible for the invasive growth property of tumours [68-70]. In Ehrlich ascites tumour (EAT) cells a time-dependent inhibition of VEGF and key growth factor angiopoietin was observed, combined with an anti-proliferative effect on HUVECs, this being attributed directly to VEGF and NF- $\kappa B$ inhibition $[71,72]$. Other reported actions of curcumin include inhibition of epidermal growth factor receptor (EGFR) and intracellular signalling tyrosine kinases, the latter of which are known to promote angiogenesis through gene activation of cyclooxygenase-2, IL-2 and MMPs [73-75]. Derivatives of curcumin have also being investigated with preliminary findings pointing towards an increase in antitumor activity, although further corroborative studies are necessary to confirm these findings [76-78]. 


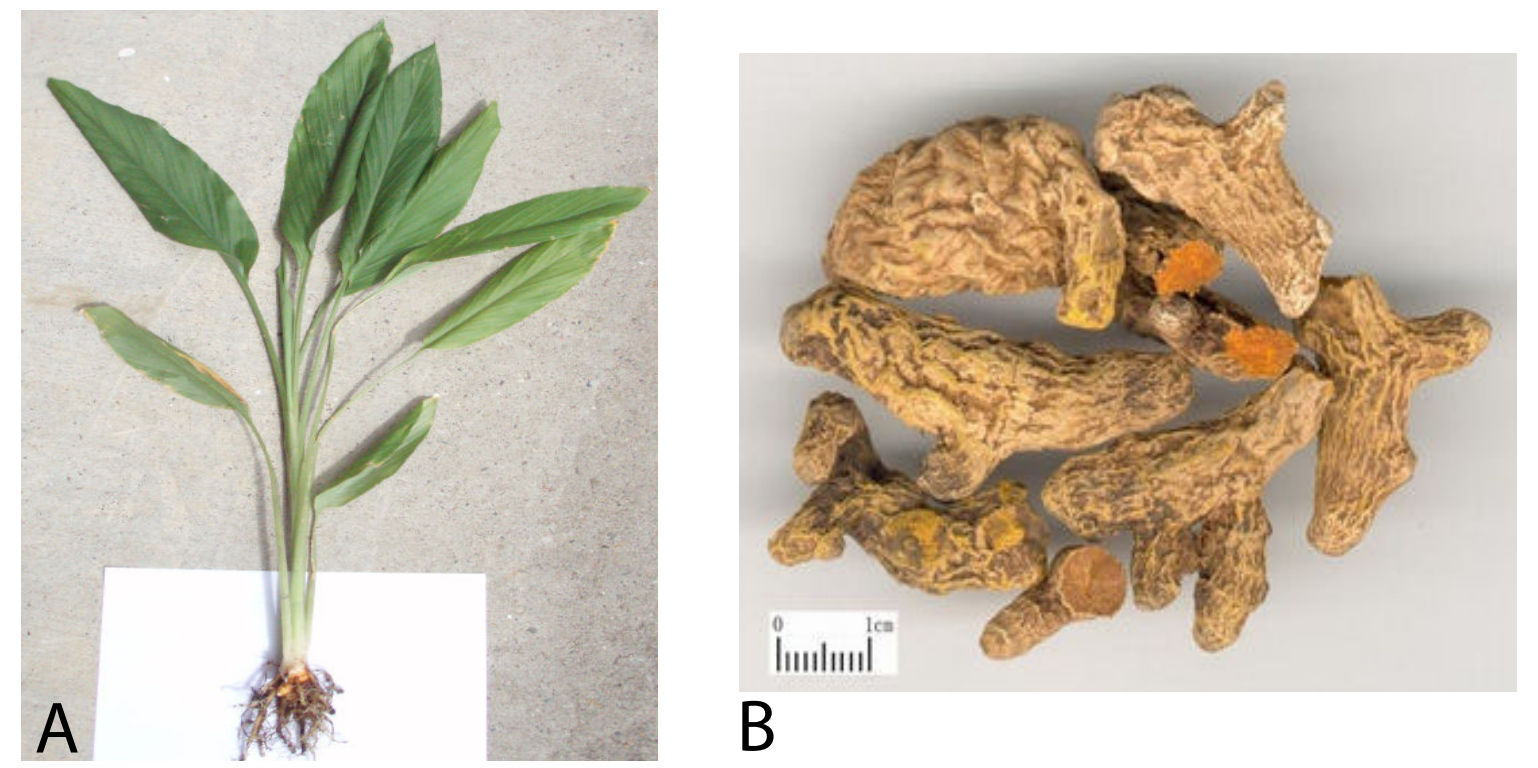

\section{Figure 4}

Plant (A) and root (B) of Curcuma longa ('curcumin') where root scale is shown as $I \mathrm{~cm}$.

TCM often possess quite distinct and specialised modes of action, and consequently tumours normally resistant to conventional chemotherapy are reported to be more susceptible to TCM therapy [79]. They have demonstrable and often direct inhibitory effects on tumour cell growth and proliferation, affecting different stages of the cell growth cycle and mitotic phase [80]. Herbal compounds such as paclitaxel $\left(\mathrm{Taxol}^{\circledR}\right)$ and its derivatives suppress microtubule depolymerization, thus terminating cell mitosis [81]. As a result these, and compounds including harringtonine (Cephalotaxus hainanensis) and camptothecin (Camptotheca acuminata) with similar mechanisms of action are already commonly used in the clinic as anticancer agents for a variety of cancers [82]. The mechanism of action of camptothecin (Camptotheca acuminata) being to inhibit DNA topoisomerase I, consequently affecting DNA replication; paclitaxel is a mitotic spindle inhibitor (spindle poison), which can also bind with tubulin and prevent the normal physiological process of microtubule depolymerization.

Anticancer properties of the TCM elemene (Rhizoma Zedoariae) and oridonin (Rabdosia rubescens) lend themselves to being co-administered with conventional chemotherapeutic agents (e.g. doxorubicin and 5-fluorouracil (5-FU)) to impart a synergistic anti-tumour effect. Combining elemene (Rhizoma Zedoariae) with the pyrimidine base analogue 5-FU, resulted in significantly higher tumour growth inhibitive effects [83]. The anti-tumour activity of another TCM, 'half-flag' (Pteris semipinnata L. -
Figure 5) was also significant, being shown to inhibit DNA production in HL- 60 cells by $41 \%$ when combined with 5 -FU, compared to only $10 \%$ in cells treated with the TCM alone. Half-flag also improved the anticancer efficiency of several other chemotherapeutic drugs when used concomitantly [84].

Similarly, derivatives of the herbal compound berbamine (Berberis amurensis), namely EBB (O-(4-ethoxyl-butyl)berbamine) when combined with cyclophosphamide and mitomycin-C respectively enhanced the antitumor capacity, while also significantly improving patients' quality of life [85]. Zhang and co-workers tested 20 natural flavonoid compounds in breast cancer cell lines discovering they assist in the intracellular accumulation of anthracycline drugs while also reversing anthracene resistance $[86,87]$. Kim SW et al., reported that ginsenoside- $\mathrm{Rg}_{3}$ (Panax ginsenoside $\mathrm{Rg}_{3}$ ) promotes Rhodamine-123 accumulation in vincristine-resistant KBV20C human fibroblast cancer cells, reversing vincristine resistance acquired by a variety of cells [88].

The discovery that single components within TCM have the potential to overcome multidrug resistance developed by tumour cells opens the door to new avenues of multidrug/TCM therapy. These findings justify and moreover pave the way for them to be used alongside conventional drugs, where significant resistance to therapy has already developed. 
Although only one clinical trial using TCM was reported up until 2001 it was poorly controlled and any conclusions drawn were deemed unreliable, it is noteworthy however that given the very recent attention being received by TCM a re-analysis study has since been conducted $[89,90]$. This raises the call for more well-defined, robust and regulated clinical trials on TCM to ensure reliable data is generated which would enable regulatory authorities and clinicians alike to make well-informed decisions when considering their incorporation into western formularies.

\section{Conclusion}

In treating diseases/illnesses of a systemic nature the typical route of TCM administration is oral. This is deemed a far from optimal approach in cancer patients given patient-to-patient variability when formulating TCM, the unpredictable absorption profile of the various bioactives across the gastrointestinal tract together with compliance issues. Furthermore, the challenge of ensuring batch-tobatch reproducibility of any given formulation remains, although the adoption of cutting-edge genetic/chemical fingerprinting in conjunction with micro-array-based cell line testing offers unique solutions to this. With modern techniques of isolation, characterisation and functionalisation of compounds along with in vitro/in vivo testing now common place within research facilities where drug discovery and delivery is a focus, the drive to engineer well-defined, targeted drug delivery systems offers a new dawn for this very traditional practice of medicine [91-

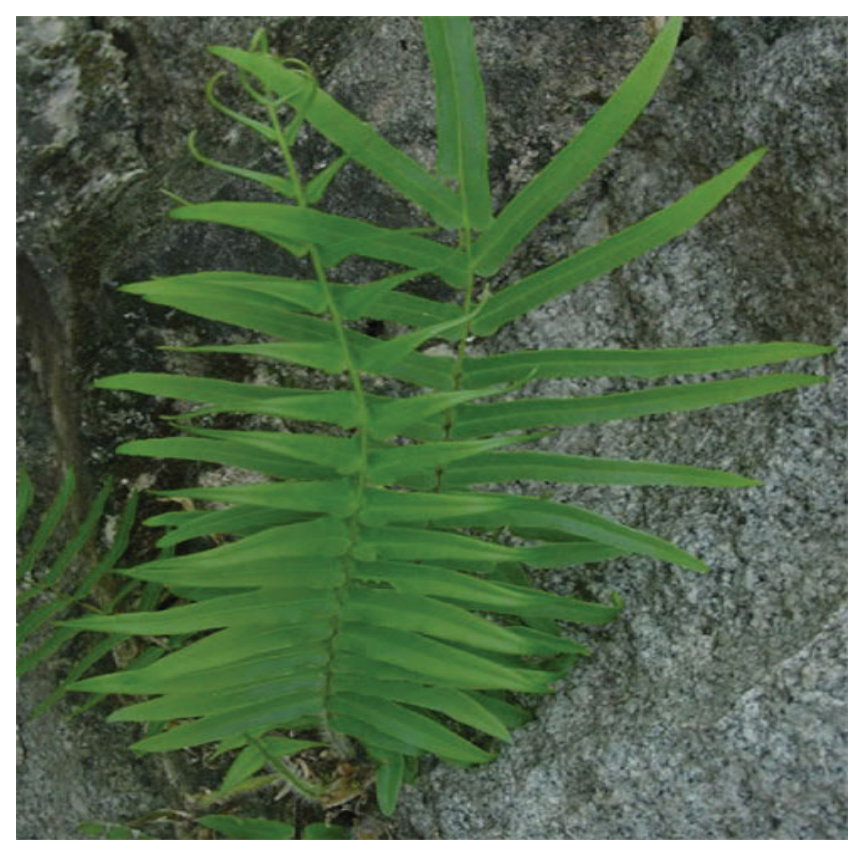

Figure 5

Plant of Pteris semipinnata L. ('half-flag').
93]. By identifying potent bioactives derived from TCM as discussed above, and tailoring formulations that encapsulate/incorporate them into cutting-edge drug delivery systems for parenteral administration one can envision overcoming the shortfalls that have prevented TCM being accepted by the West as a real adjunct/alternative to conventional cancer therapies. With a library of over 250,000 individual therapeutic compounds at our disposal, many of which have yet to be successfully isolated and tested for both safety and efficacy, there are certainly challenges that lay ahead - the scope and scale of which could well revolutionise drug discovery and delivery in the fight against cancer, for many decades to come.

\section{Competing interests}

The authors declare that they have no competing interests.

\section{Authors' contributions}

HSP drafted and wrote the manuscript. MQW revised the manuscript critically for important and intellectual content. GL provided translation of articles written in Chinese and revised the manuscript for intellectual content. All authors read and approved the final manuscript.

\section{Acknowledgements}

The authors thank Dr Kathryn Steadman, School of Pharmacy, University of Queensland for proof-reading the manuscript and valuable feedback; Helen Xia for providing plant \& root photographs.

\section{References}

I. Taiwan: time to end the exile. Lancet 1999, 354:2093-2093.

2. Igney FH, Krammer PH: Death and anti-death: Tumour resistance to apoptosis. Nature Reviews Cancer 2002, 2:277-288.

3. Schmitz I, Kirchhoff S, Krammer PH: Regulation of death receptor-mediated apoptosis pathways. Int J Biochem Cell Biol 2000, 32:I I23-I I36.

4. Kwon K-B, Park B-H, Ryu D-G: Chemotherapy through mitochondrial apoptosis using nutritional supplements and herbs: A brief overview. J Bioenerg Biomembr 2007, 39:3 I-34.

5. Klein G: Cancer, apoptosis, and nonimmune surveillance. Cell Death Differ 2004, I I : I3-I7.

6. Ruan W-J, Lai M-D, Zhou J-G: Anticancer effects of Chinese herbal medicine, science or myth? Journal of Zhejiang University, Science, B 2006, 7:1006-1014.

7. Luk JM, Wang X, Liu P, Wong K-F, Chan K-L, Tong Y, Hui C-K, Lau GK, Fan S-T: Traditional Chinese herbal medicines for treatment of liver fibrosis and cancer: from laboratory discovery to clinical evaluation. Liver Int 2007, 27:879-890.

8. Green DR, Evan GI: A matter of life and death. Cancer Cell 2002, I:I9-30.

9. Petit PX, Susin SA, Zamzami N, Mignotte B, Kroemer G: Mitochondria and programmed cell death: Back to the future. FEBS Lett 1996, 396:7-13.

10. Bossy-Wetzel E, Green DR: Apoptosis: checkpoint at the mitochondrial frontier. Mutation Research, DNA Repair 1999, 434:243-25I.

II. Rathmell JC, Thompson CB: The central effectors of cell death in the immune system. Annu Rev Immunol 1999, I 7:781-828.

12. Janssen-Heininger YMW, Poynter ME, Baeuerle PA: Recent advances towards understanding redox mechanisms in the activation of nuclear factor kb. Free Radical Biology \& Medicine 2000, 28: I317-1327.

13. Baeuerle PA, Henkel T: Function and activation of NF-kappa B in the immune system. Annu Rev Immunol 1994, I 2:141-179. 
14. Baeuerle PA, Rupec RA, Pahl HL: Reactive oxygen intermediates as second messengers of a general pathogen response. Pathologie Biologie 1996, 44:29-35.

I5. Pahl HL: Activators and target genes of Rel/NF-kappa B transcription factors. Oncogene I999, I 8:6853-6866.

16. Shishodia S, Aggarwal BB: Nuclear factor-kappa B activation: A question of life or death. J Biochem Mol Biol 2002, 35:28-40.

17. Li BQ, Fu T, Gong WH, Dunlop N, Kung HF, Yan YD, Kang J, Wang JM: The flavonoid baicalin exhibits anti-inflammatory activity by binding to chemokines. Immunopharmacology 2000, 49:295-306.

18. Chi YS, Lim H, Park H, Kim HP: Effects of wogonin, a plant flavone from Scutellaria radix, on skin inflammation: in vivo regulation of inflammation-associated gene expression. Biochem Pharmacol 2003, 66:1271-1278.

19. Yu HQ, Rafi MM, Ho CT: Targeting inflammation using Asian herbs. In Herbs: Challenges in Chemistry and Biology Edited by: Ho CT. Oxford: Oxford University Press; 2006:266-280.

20. Tan $\mathrm{BKH}$, Vanitha J: Immunomodulatory and antimicrobial effects of some traditional Chinese medicinal herbs: A review. Curr Med Chem 2004, I I: I423-I 430.

21. Nelson PS, Montgomery B: Unconventional therapy for prostate cancer: Good, bad or questionable? Nature Reviews Cancer 2003, 3:845-858

22. Po LS, Chen ZY, Tsang DSC, Leung LK: Baicalein and genistein display differential actions on estrogen receptor (ER) transactivation and apoptosis in MCF-7 cells. Cancer Lett 2002, I 87:33-40.

23. Powell CB, Fung P, Jackson J, Dall'Era J, Lewkowicz D, Cohen I, SmithMcCune K: Aqueous extract of herb Scutellaria barbatae, a Chinese herb used for ovarian cancer, induces apoptosis of ovarian cancer cell lines. Gynecol Oncol 2003, 91 1:332-340.

24. Ye F, Xui L, Yi JZ, Zhang WD, Zhang DY: Anticancer activity of Scutellaria baicalensis and its potential mechanism. J Altern Complement Med 2002, 8:567-572.

25. Pidgeon GP, Kandouz M, Meram A, Honn KV: Mechanisms controlling cell cycle arrest and induction of apoptosis after I 2lipoxygenase inhibition in prostate cancer cells. Cancer Res 2002, 62:2721-2727.

26. Burnett BP, Jia Q, Zhao Y, Levy RM: A medicinal extract of Scutellaria baicalensis and Acacia catechu acts as a dual inhibitor of cyclooxygenase and 5-lipoxygenase to reduce inflammation. J Med Food 2007, I 0:442-45I.

27. Chan FL, Choi HL, Chen ZY, Chan PSF, Huang Y: Induction of apoptosis in prostate cancer cell lines by a flavonoid, baicalin. Cancer Lett 2000, 160:219-228.

28. Kwon K-B, Kim E-K, Shin B-C, Seo E-A, Park J-W, Kim J-S, Park B-H, Ryu D-G: Induction of apoptosis by takrisodokyeum through generation of hydrogen peroxide and activation of caspase-3 in HL-60 cells. Life Sci 2003, 73:1895-1906.

29. Sahara S, Aoto M, Eguchi Y, Imamoto N, Yoneda Y, Tsujimoto Y: Acinus is a caspase-3-activated protein required for apoptotic chromatin condensation. Nature 1999, 40 I: I68-173.

30. Sebbagh M, Renvoize C, Hamelin J, Riche N, Bertoglio J, Breard J: Caspase-3-mediated cleavage of ROCK I induces MLC phosphorylation and apoptotic membrane blebbing. Nat Cell Biol 2001, 3:346-352

31. Kwon KB, Kim EK, Han MJ, Shin BC, Park YK, Kim KS, Lee YR, Park JW, Park BH, Ryu DG: Induction of apoptosis by Radix Paeoniae alba extract through cytochrome $c$ release and the activations of caspase-9 and caspase-3 in HL-60 cells. Biol Pharm Bull 2006, 29:1082-1086

32. DiPietrantonio AM, Hsieh T-C, Wu JM: Activation of caspase 3 in HL-60 cells exposed to hydrogen peroxide. Biochem Biophys Res Commun 1999, 255:477-482.

33. Sung HJ, Choi SM, Yoon Y, An KS: Tanshinone IIA, an ingredient of Salvia miltiorrhiza bunge, induces apoptosis in human leukemia cell lines through the activation of caspase-3. Exp Mol Med 1999, 31:174-178.

34. Yoon Y, Kim YO, Jeon WK, Park JH, Sung HJ: Tanshinone IIA isolated from Salvia miltiorrhiza bunge induced apoptosis in HL60 human premyelocytic leukemia cell line. J Ethnopharmacol 1999, 68:121-127.

35. Lee H, Kim YJ, Kim HW, Lee DH, Sung M-K, Park T: Induction of apoptosis by Cordyceps militaris through activation of cas- pase-3 in leukemia HL-60 cells. Biol Pharm Bull 2006, 29(4):670-674.

36. Liu WK, Cheung FWK, Che C-T: Stellettin A Induces Oxidative Stress and Apoptosis in HL-60 Human Leukemia and LNCaP Prostate Cancer Cell Lines. J Nat Prod 2006, 69:934-937.

37. Walczak H, Miller RE, Ariail K, Gliniak B, Griffith TS, Kubin M, Chin W, Jones J, Woodward A, Le T, et al.: Tumoricidal activity of tumor necrosis factor related apoptosis-inducing ligand in vivo. Nat Med 1999, 5:157-163.

38. Nagane M, Pan GH, Weddle JJ, Dixit VM, Cavenee WK, Huang HJS: Increased death receptor 5 expression by chemotherapeutic agents in human gliomas causes synergistic cytotoxicity with tumor necrosis factor-related apoptosis-inducing ligand in vitro and in vivo. Cancer Res 2000, 60:847-853.

39. Chinnaiyan AM, Prasad U, Shankar S, Hamstra DA, Shanaiah M, Chenevert TL, Ross BD, Rehemtulla A: Combined effect of tumor necrosis factor-related apoptosis-inducing ligand and ionizing radiation in breast cancer therapy. Proc Natl Acad Sci USA 2000, 97:1754-1759.

40. Keane MM, Ettenberg SA, Nau MM, Russell EK, Lipkowitz S: Chemotherapy augments TRAIL-induced apoptosis in breast cell lines. Cancer Res 1999, 59:734-74I.

4I. Kupchan SM, Bryan RF, Gilmore C], Dailey RG, Court WA: Tumor inhibitors .74. triptolide and tripdiolide, novel antileukemic diterpenoid triepoxides from tripterygium-wilfordii. J Am Chem Soc 1972, 94:7194-5.

42. Frese S, Pirnia F, Miescher D, Krajewski S, Borner MM, Reed JC, Schmid RA: PG490-mediated sensitization of lung cancer cells to Apo2L/TRAIL-induced apoptosis requires activation of ERK2. Oncogene 2003, 22:5427-5435.

43. Lee KY, Chang WT, Qiu DM, Kao PN, Rosen GD: PG490 (triptolide) cooperates with tumor necrosis factor-alpha to induce apoptosis in tumor cells. J Biol Chem 1999, 274: $1345 \mid-13455$.

44. Chang WT, Kang JJ, Lee KY, Wei K, Anderson E, Gotmare S, Ross JA, Rosen GD: Triptolide and chemotherapy cooperate in tumor cell apoptosis - A role for the $\mathbf{p 5 3}$ pathway. I Biol Chem 200I, 276:222 I-2227

45. Sprick MR, Weigand MA, Rieser E, Rauch CT, Juo P, Blenis J, Krammer $\mathrm{PH}$, Walczak $\mathrm{H}$ : FADD/MORTI and caspase-8 are recruited to TRAIL receptors $I$ and 2 and are essential for apoptosis mediated by TRAIL receptor 2 . Immunity 2000 , I 2:599-609.

46. Kischkel FC, Lawrence DA, Chuntharapai A, Schow P, Kim KJ, Ashkenazi A: Apo2L/TRAIL-dependent recruitment of endogenous FADD and caspase- 8 to death receptors 4 and 5 . Immunity 2000, I 2:6 I I-620.

47. Walczak H, Krammer PH: The CD95 (APO-I/Fas) and the TRAIL (APO-2L) apoptosis systems. Exp Cell Res 2000, 256:58-66.

48. Carter BZ, Mak DH, Schober WD, McQueen T, Harris D, Estrov Z, Evans RL, Andreeff $M$ : Triptolide induces caspase-dependent cell death mediated via the mitochondrial pathway in leukemic cells. Blood 2006, I 08:630-637.

49. Daniel PT: A TRAIL to Chinese herbal medicine. Blood 2006 , 108:3634.

50. Folkman J, Bach M, Rowe JW, Davidoff F, Lambert P, Hirsch C, Goldberg A, Hiatt HH, Glass J, Henshaw E: Tumor angiogenesis - therapeutic implications. $N$ Engl J Med I 97I, 285: I I 82.

51. Yance DR Jr, Sagar SM: Targeting angiogenesis with integrative cancer therapies. Integr Cancer Ther 2006, 5:9-29.

52. Shweiki D, Itin A, Soffer D, Keshet E: Vascular endothelial growth-factor induced by hypoxia may mediate hypoxia-initiated angiogenesis. Nature 1992, 359:843-845.

53. Shima DT, Deutsch U, Damore PA: Hypoxic induction of vascular endothelial growth-factor (VEGF) in human epithelial-cells is mediated by increases in messenger-RNA stability. FEBS Lett 1995, 370:203-208.

54. Risau W: Mechanisms of angiogenesis. Nature 1997, 386:67I-674.

55. Toi M, Matsumoto $T$, Bando $H$ : Vascular endothelial growth factor: its prognostic, predictive, and therapeutic implications. Lancet Oncol 2001, 2:667-673.

56. Efferth T, Dunstan H, Sauerbrey A, Miyachi H, Chitambar CR: The anti-malarial artesunate is also active against cancer. Int Oncol 200I, 18:767-773. 
57. Efferth T, Davey M, Olbrich A, Rucker G, Gebhart E, Davey R: Activity of drugs from traditional Chinese medicine toward sensitive and MDRI- or MRPI-overexpressing multidrugresistant human CCRF-CEM leukemia cells. Blood Cells Molecules and Diseases 2002, 28:160-168.

58. Mueller MS, Runyambo N, Wagner I, Borrmann S, Dietz K, Heide L: Randomized controlled trial of a traditional preparation of Artemisia annua L. (Annual Wormwood) in the treatment of malaria. Trans $R$ Soc Trop Med Hyg 2004, 98:3 I8-32I.

59. Chen HH, Zhou HJ, Wu GD, Lou XE: Inhibitory effects of artesunate on angiogenesis and on expressions of vascular endothelial growth factor and VEGF receptor KDR/flk-I. Pharmacology 2004, 7 I: I-9.

60. Zhou H-J, Wang W-Q, Wu G-D, Lee J, Li A: Artesunate inhibits angiogenesis and downregulates vascular endothelial growth factor expression in chronic myeloid leukemia $\mathrm{K562}$ cells. Vascul Pharmacol 2007, 47:131-138.

61. Chen HH, Zhou HJ, Fan X: Inhibition of human cancer cell line growth and human umbilical vein endothelial cell angiogenesis by artemisinin derivatives in vitro. Pharmacol Res 2003, 48:23I-236.

62. Efferth T, Sauerbrey A, Olbrich A, Gebhart E, Rauch P, Weber HO, Hengstler JG, Halatsch ME, Volm M, Tew KD, et al:: Molecular modes of action of artesunate in tumor cell lines. Mol Pharmacol 2003, 64:382-394.

63. Narayan S: Curcumin, A Multi-Functional Chemopreventive Agent, Blocks Growth of Colon Cancer Cells by Targeting $\beta$ Catenin-Mediated Transactivation and Cell-Cell Adhesion Pathways. J Mol Histol 2004, 35:30I-307.

64. Sen S, Sharma H, Singh N: Curcumin enhances Vinorelbine mediated apoptosis in NSCLC cells by the mitochondrial pathway. Biochem Biophys Res Commun 2005, 33 I: I245-1252.

65. Khafif A, Hurst R, Kyker K, Fliss Dan M, Gil Z, Medina Jesus E: Curcumin: a new radio-sensitizer of squamous cell carcinoma cells. Otolaryngol Head Neck Surg 2005, 132:317-321.

66. Arbiser JL, Klauber N, Rohan R, Van Leeuwen R, Huang M-T, Fisher C, Flynn $E$, Byers HR: Curcumin is an in vivo inhibitor of angiogenesis. Molecular Medicine 1998, 4:376-383.

67. Shao ZM, Shen ZZ, Liu CH, Sartippour MR, Go VL, Heber D, Nguyen M: Curcumin exerts multiple suppressive effects on human breast carcinoma cells. Int J Cancer 2002, 98:234-240.

68. Stetler-Stevenson WG, Yu AE: Proteases in invasion: matrix metalloproteinases. Semin Cancer Biol 200 I, I I:143-153.

69. Stetler-Stevenson WG, Seo D-W: Matrix metalloproteinases in tumor progression. Cancer Metastasis - Biology and Treatment 2006 8:143-158.

70. Chen H-W, Yu S-L, Chen JJW, Li H-N, Lin Y-C, Yao P-L, Chou H-Y, Chien C-T, Chen W-J, Lee Y-T, Yang P-C: Anti-invasive gene expression profile of curcumin in lung adenocarcinoma based on a high throughput microarray analysis. Mol Pharmacol 2004, 65:99-1 I0.

7I. Gururaj AE, Belakavadi M, Venkatesh DA, Marme D, Salimath BP: Molecular mechanisms of anti-angiogenic effect of curcumin. Biochem Biophys Res Commun 2002, 297:934-942.

72. Bachmeier BE, Nerlich AG, lancu CM, Cilli M, Schleicher E, Vene R, Dell'Eva R, Jochum M, Albini A, Pfeffer U: The chemopreventive polyphenol Curcumin prevents hematogenous breast cancer metastases in immunodeficient mice. Cell Physiol Biochem 2007, I9:| 37-I52.

73. Reddy S, Aggarwal BB: Curcumin is a noncompetitive and selective inhibitor of phosphorylase-kinase. FEBS Lett 1994, 341:19-22.

74. Dorai T, Cao YC, Dorai B, Buttyan R, Katz AE: Therapeutic potential of curcumin in human prostate cancer. III. Curcumin inhibits proliferation, induces apoptosis, and inhibits angiogenesis of LNCaP prostate cancer cells in vivo. Prostate 200I, 47:293-303.

75. Leu TH, Su SL, Chuang YC, Maa MC: Direct inhibitory effect of curcumin on Src and focal adhesion kinase activity. Biochem Pharmacol 2003, 66:2323-233I.

76. Kim JH, Shim JS, Lee SK, Kim KW, Rha SY, Chung HC, Kwon HJ: Microarray-based analysis of anti-angiogenic activity of demethoxycurcumin on human umbilical vein endothelial cells: Crucial involvement of the down-regulation of matrix metalloproteinase. Jpn J Cancer Res 2002, 93:1378-1385.
77. Shim JS, Kim DH, Jung HJ, Kim JH, Lim D, Lee SK, Kim KW, Ahn JW, Yoo JS, Rho JR, et al: Hydrazinocurcumin, a novel synthetic curcumin derivative, is a potent inhibitor of endothelial cell proliferation. Bioorg Med Chem 2002, 10:2987-2992.

78. John VD, Kuttan G, Krishnankutty K: Anti-tumour studies of metal chelates of synthetic curcuminoids. J Exp Clin Cancer Res 2002, $21: 219-224$.

79. Shi Z-M, Tian J-H: Correlative factors for cancer response evaluation treated by TCM. Shanghai Journal of Traditional Chinese Medicine 2006, 40:16-18.

80. Li Y, Ming Y-W: Molecular mechanism of Chinese anti-tumor herbal medicine. Chinese Journal of Information on TCM 2005, I 2:95-96.

81. Kaye SB: Progress in the treatment of ovarian cancer. Anticancer Drugs 1999, 10:S29-S32.

82. Wang S-Z, Yang J-Y: Development of Clinical Applications for Anti-tumor Botanicals and Semi-Synthetic Medicine. Journa of Xin Jiang Medical University 200I, 24: I 83-I84.

83. Zheng $X, \mathrm{He} M-X, B$ in $L$, et al.: Effects of elemene combined with chemotherapy drugs on the growth of cancer cells. Cancer Prevention and Control Research 1998, 25:220-22I.

84. Li J, Liang N, Mo L, He C, Zhang X: Effect of compound 6F isolated from Pteris semipinnata on cell cycle and synthesis of DNA, RNA and protein of lung adenocarcinoma cell. Chinese Pharmacology 1999, 15:49-5 |.

85. Zhang J, Mao Q, Xu N, Chen J: Effect of berbamine derivative (EBB) on anticancer and immune function of tumor-bearing mice. Chinese Herbal Journal 1998, 29:243-246.

86. Chen J-L, Jiang S, Yang R-F, Liu F-S, Sun X-M: Mechanism of drug resistance and reversal with ligustrazine and cyclosporin $A$ in cisplatin-induced human epithelial ovarian cancer resistant cell line 3Ao/cDDP. Chinese Journal of Cancer Research 2000, I 2:197-203

87. Kim S-H, Yeo G-S, Lim Y-S, Kang C-D, Kim C-M, Chung B-S: Suppression of multidrug resistance via inhibition of heat shock factor by quercetin in MDR cells. Exp Mol Med 1998, 30:87-92.

88. Kim S-W, Kwon H-y, Chi D-W, Shim J-H, Park J-D, Lee Y-H, Pyo S, Rhee D-K: Reversal of P-glycoprotein-mediated multidrug resistance by ginsenoside Rg3. Biochem Pharmacol 2003, 65:75-82.

89. Grossarth-Maticek R, Kiene H, Baumgartner SM, Ziegler R: Use of Iscador, an extract of European mistletoe (Viscum album), in cancer treatment: Prospective nonrandomized and randomized matched-pair studies nested within a cohort study. Altern Ther Health Med 200I, 7:57.

90. Grossarth-Maticek R, Ziegler R: Randomised and non-randomised prospective controlled cohort studies in matchedpair design for the long-term therapy of breast cancer patients with a mistletoe preparation (Iscador): A re-analysis. Eur J Med Res 2006, I I:485-495.

9I. Parekh HS: The advance of dendrimers - a versatile targeting platform for gene/drug delivery. Curr Pharm Des 2007, 13:2837-2850.

92. Petrak K: Essential properties of drug-targeting delivery systems. Drug Discov Today 2005, 10:1667-1673.

93. Wang MD, Shin DM, Simons JW, Nie S: Nanotechnology for targeted cancer therapy. Expert Rev Anticancer Ther 2007, 7:833-837.

Publish with BioMed Central and every scientist can read your work free of charge

"BioMed Central will be the most significant development for disseminating the results of biomedical research in our lifetime. "

Sir Paul Nurse, Cancer Research UK

Your research papers will be:

- available free of charge to the entire biomedical community

- peer reviewed and published immediately upon acceptance

- cited in PubMed and archived on PubMed Central

- yours - you keep the copyright 